\title{
Analisis Faktor Terpenting yang Mempengaruhi Corak Hubungan Malaysia-Australia Era Mahathir Mohamad, 1981-2003
}

\section{Salient Factors Affecting Malaysia-Australia Patterns of Relationship in the Era of Mahathir Mohamad, 1981-2003}

\author{
RIZAL ZAMANI IDRIS \\ ${ }^{*}$ ASMADY IDRIS \\ Fakulti Sains Sosial dan Kemanusiaan, Universiti Malaysia Sabah, Jalan UMS, \\ 88400 Kota Kinabalu, Sabah, Malaysia \\ *Corresponding author: asmadyi@ums.edu.my
}

Published online: 29 October 2021

To cite this article: Rizal Zamani Idris and Asmady Idris. 2021. Analisis faktor terpenting yang mempengaruhi corak hubungan Malaysia-Australia era Mahathir Mohamad, 1981-2003. KEMANUSIAAN the Asian Journal of Humanities 28(2): 53-78. https://doi.org/10.21315/kajh2021 .28 .2 .3

To link to this article: https://doi.org/10.21315/kajh2021.28.2.3

\begin{abstract}
Malaysia-Australia diplomatic relations was established as early as in 1955 when an Australian High Commission was set up in Kuala Lumpur and was later formalised in 1957 when Malaysia gained its independence. Both countries cooperated closely in the areas of defence, education, and trade. Australia regarded Malaysia as its closest ally in the region. However, things began to change when Tun Dr. Mahathir Mohamad became Malaysia's Prime Minister (1981-2003). Ties between the two countries were tested with controversial issues that influenced their diplomatic relations, but the overall relationship remained intact. The current study analyses two main factors, namely souring factors, and enduring factors, that had influenced the pattern and character of the Malaysia-Australia relations in the era of Mahathir. It utilised a combination of methods, i.e. discussions from the English School theory, data collection through document analysis and interviews. The study found that the pattern of the Malaysia-Australia relations could be best understood and explained by the arguments offered by the English School theory of international relations. This is an important contribution to the study of Malaysia-Australia relations during Mahathir's era.
\end{abstract}

Keywords and phrases: Malaysia, Australia, Mahathir, souring factors, enduring factors, diplomatic relations 


\begin{abstract}
Abstrak. Hubungan diplomatik Malaysia-Australia telah terjalin seawal 1955 apabila pejabat Pesuruhjaya Tinggi Australia ditubuhkan di Kuala Lumpur dan dimeterai secara rasmi apabila Malaysia mencapai kemerdekaan pada tahun 1957. Kedua-dua negara ini telah bekerjasama dalam pelbagai bidang seperti pertahanan, pendidikan, perdagangan dan lain-lain. Malah, Australia menganggap Malaysia sebagai sekutu paling rapat di rantau ini. Sungguhpun begitu, hubungan ini mula berubah apabila Tun Dr. Mahathir Mohamad menjadi Perdana Menteri Malaysia (1981-2003). Hubungan bilateral Malaysia-Australia telah diuji dengan beberapa isu kontroversi. Isu-isu tersebut telah mempengaruhi hubungan Malaysia dan Australia namun tidaklah menjejaskan hubungan dua hala secara keseluruhannya. Kajian ini menganalisis faktor terpenting yang telah mempengaruhi corak dan karakter hubungan Malaysia dan Australia era Mahathir. Faktor terpenting ini dibahagikan kepada dua: faktor "pengeruh" (souring factor) dan faktor "pengukuh" (enduring factor). Metodologi kajian adalah berdasarkan gabungan perbincangan menggunakan teori English School, pemerolehan data secara analisis dokumen dan temu bual. Pada akhir kajian ini, penulis mendapati bahawa corak hubungan Malaysia dan Australia pada era Mahathir dapat difahami dan dijelaskan dengan baik melalui perspektif yang diutarakan oleh teori English School. Oleh yang demikian, hal inilah yang menjadi sumbangan utama makalah ini dalam kajian hubungan Malaysia-Australia di bawah kepimpinan Mahathir.
\end{abstract}

Kata kunci dan frasa: Malaysia, Australia, Mahathir, faktor pengeruh, faktor pengukuh, hubungan diplomatik

\title{
Pengenalan $^{1}$
}

Hubungan diplomatik antara Malaysia dengan Australia telah bermula sekitar tahun 1955 lagi dengan penubuhan sebuah pejabat Pesuruhjaya (sekarang Pejabat Pesuruhjaya Tinggi Australia) di Kuala Lumpur (Australia-Malaysia Institute 2007). Setelah Malaysia mencapai kemerdekaan pada tahun 1957, pelbagai ikatan kerjasama dibentuk khasnya dalam aspek keselamatan, pertahanan, pendidikan dan perdagangan. Walaupun demikian, hubungan baik antara Malaysia dengan Australia sentiasa berhadapan cabaran terutamanya ketika era Tun Dr. Mahathir Mohamad yang menjadi Perdana Menteri Malaysia keempat pada tahun 1981. Pelbagai isu kontroversi telah timbul dan sedikit sebanyak mempengaruhi corak hubungan Malaysia dan Australia. Namun demikian, di sebalik kesan negatif daripada isu-isu kontroversi tersebut, hubungan keduadua negara pada era Mahathir tetap utuh. Beberapa persoalan penting akan difokuskan dalam konteks perbincangan ini. Antara persoalan tersebut ialah "Apakah punca yang membawa kepada ketegangan hubungan bilateral Malaysia dan Australia?", "Sejauh manakah implikasi situasi ketegangan tersebut?", "Bagaimanakah reaksi para pemimpin dan rakyat kedua-dua negara terhadap siri kontroversi yang berlaku?" dan "Apakah penjelasan yang boleh dikemukakan 
terhadap faktor yang menjadi 'pengikat' kepada hubungan dua hala negara ini di sebalik ketegangan dan kontroversi yang berlaku?”.

Oleh itu, kajian ini akan membincangkan bagaimana hubungan rapat MalaysiaAustralia dapat dikekalkan semasa era Mahathir (1981-2003) biarpun berhadapan dengan deretan isu kontroversi yang boleh menjejaskan hubungan dua hala. Bagi menjelaskan persoalan yang diutarakan, kajian ini akan memfokuskan kepada dua faktor utama iaitu "faktor pengeruh" (souring factor) dan "faktor pengukuh" (enduring factor). Faktor pengeruh adalah berkait rapat dengan lima isu yang bersifat kontroversi dan respons negatif dari pihak Australia terhadap Malaysia manakala faktor pengukuh merujuk kepada elemen yang mengikat kedua-dua negara untuk sentiasa berinteraksi walaupun wujudnya pelbagai rintangan. Huraian kedua-dua faktor akan dianalisis dari sudut teori English School yang memberi penekanan kepada nilai dan elemen persamaan yang wujud antara negara terlibat bagi mengelakkan sebarang keretakan dalam hubungan mereka pada peringkat antarabangsa. Secara tidak langsung, pendekatan teori ini amat bersesuaian dalam menjelaskan hubungan Malaysia-Australia sungguhpun dilanda pelbagai isu kontroversi semasa era Mahathir.

Skop perbincangan kajian ini akan dibahagikan kepada enam perkara. Perkara pertama akan menyentuh perihal hubungan awal Malaysia-Australia sejak tahun 1957. Perkara kedua dan ketiga akan menganalisis faktor pengeruh serta elemen utama yang memperkuatkan faktor pengeruh. Perkara keempat dan kelima menyentuh keutuhan hubungan bilateral kedua-dua negara dan membincangkan faktor-faktor pengukuh. Manakala, perkara keenam ialah analisis menggunakan teori English School tentang hubungan yang masih utuh walaupun berhadapan dengan pelbagai cabaran.

Makalah ini menggunakan kaedah analisis dokumen. Analisis dilakukan terhadap penulisan berbentuk buku, jurnal akademik dan sumber internet ilmiah yang berkait dengan tajuk kajian. Selain itu, penelitian turut dilakukan terhadap media seperti surat khabar dari kedua-dua pihak Malaysia dan Australia. Dalam masa yang sama, temu bual turut dilakukan dengan Mahathir yang turut menjadi key informant (pemberi maklumat utama) dalam kajian ini. Sumbangan utama makalah ini dan perbezaannya dengan kajian lampau tentang hubungan Malaysia-Australia ialah ia menggunakan teori English School sebagai kerangka pendekatan teori. Teori ini memberikan peluang untuk perbahasan yang lebih komprehensif dan kritis terhadap hubungan kedua-dua negara. 


\section{Hubungan Awal Malaysia-Australia}

Hubungan awal antara Malaysia dengan Australia telah bermula sejak sebelum merdeka dan berkembang dengan baik pasca merdeka 1957. Pada dasarnya, interaksi kedua-dua negara di awal kemerdekaan sehingga tahun 1970-an adalah lebih berdasarkan kepada isu keselamatan seperti penglibatan tentera Australia yang membantu Malaya (kini Malaysia) dan Borneo semasa Perang Dunia Kedua, Peristiwa Darurat (1948-1960) bagi membendung pengaruh Komunis serta ancaman Konfrontasi Indonesia dan Filipina pada tahun 1965 (Cochrane 2001, 203). Komitmen padu Australia mempertahankan kedaulatan Malaysia adalah seperti yang diutarakan oleh Perdana Menteri Australia ke-12, Robert Menzies:

If there occurs, in relation to Malaysia... armed invasion or subversive activity...we shall to the best of our powers...add our military assistance...in the defence of Malaysia's territorial integrity and political independence. (Thayer 1992, 269)

Selain daripada itu, kedua-dua negara juga menjayakan penubuhan Five Power Defence Arrangements (FPDA) pada tahun 1971 yang turut dianggotai oleh Britain, New Zealand dan Singapura (Fraser 2001, 220; Williams 1992, 2; Thayer 1992, 269).

Dari aspek lain pula, Australia telah memberi sumbangan bermakna bagi Malaysia sebagai negara yang baru sahaja mencapai kemerdekaan seperti menaja permohonan keahlian Malaysia dalam Pertubuhan Bangsa-Bangsa Bersatu (PBB) dan menawarkan khidmat beberapa individu penting Australia termasuklah Sir William McKell (bekas Gabenor Jeneral Australia) dalam Suruhanjaya Reid dan Tan Sri William Wilcock sebagai Gabenor pertama Bank Negara Malaysia (Wollcott 2003, 52-69). Selanjutnya, pentadbiran Canberra juga menawarkan tajaan biasiswa melalui Rancangan Colombo kepada rakyat Malaysia yang berhasrat melanjutkan pelajaran di institusi pengajian tinggi Australia. Rentetan daripada kerjasama khasnya dalam hal keselamatan, pengiktirafan dan pendidikan ini, Malaysia boleh dianggap sebagai antara sahabat karib Australia di rantau ini (Marshallsay 1996, 90).

Meskipun begitu, hubungan akrab antara Malaysia dan Australia telah diuji dengan beberapa isu kontroversi semasa kepimpinan Mahathir Mohamad. Adakalanya, Malaysia dikritik oleh beberapa pemimpin Australia dan dipersenda oleh media negara berkenaan terhadap sesuatu isu. Bahkan, sistem pentadbiran negara Malaysia juga turut dipersoalkan. Oleh yang demikian, isu-isu berkenaan telah membawa kepada suasana tegang. Antara isu yang dimaksudkan adalah 
pelaksanaan hukuman mati terhadap pengedar dadah warga Australia, penayangan drama Embassy, filem Turtle Beach, kritikan Paul Keating terhadap Mahathir dan isu pemecatan Anwar Ibrahim. Kelima-lima isu inilah, sebahagian besarnya, telah mengundang kritikan negatif dari pihak Australia dan secara tidak langsung berfungsi sebagai faktor pengeruh dalam konteks hubungan dua hala pada era Mahathir. Huraian lanjut terhadap kelima-lima isu tersebut dan reaksi Australia akan dinyatakan dengan lebih terperinci dalam perbincangan seterusnya.

\section{Teori English School: Masyarakat Antarabangsa dan Order Antarabangsa}

Seperti yang dihujahkan oleh beberapa sarjana Hubungan Antarabangsa, teori English School berperanan sebagai alternatif kepada arus perdana teori hubungan antarabangsa yang didominasi khasnya oleh para ilmuan daripada benua Amerika (Dunne 2007, 127). Fokus utama teori ini adalah konsep "Masyarakat Antarabangsa". Hedley Bull sebagai seorang pelopor kepada konsep ini telah berjaya membuat perbezaan yang jelas antara konsep sistem antarabangsa dari perspektif realisme dan juga konsep masyarakat antarabangsa dari sudut pandangan teori English School. Teori English School menghujahkan negara membentuk masyarakat antarabangsa yang berkongsi kebersamaan dalam beberapa aspek seperti kepentingan, nilai, peraturan dan institusi. Konflik antara negara dapat diminimumkan melalui pemupukan daya rasa keperluan antara satu dengan yang lain bagi memelihara kepentingan bersama (Burchill 2005, 155-156).

Selain itu, salah satu daripada isu utama yang cuba diselesaikan oleh teori ini adalah fenomena "order" yang wujud pada peringkat global. Fenomena yang menjadi persoalan adalah bagaimana order boleh wujud pada peringkat antarabangsa sedangkan tidak wujud sebagai sebuah kerajaan dunia (Friedrichs 2004, 93). Dengan itu, hujah utama yang dikemukakan oleh teori ini adalah ketiadaan kerajaan dunia tidak semestinya membawa kepada ketiadaan order antarabangsa. Pandangan ini turut dipertahankan oleh Holsti yang menyatakan bahawa order antarabangsa wujud hasil daripada tiga faktor utama yang dikemukakan oleh Bull iaitu peraturan atau undang-undang seperti saling mengiktiraf kedaulatan negara, institusi-institusi yang mendokong peraturan tersebut dan yang paling utama adalah kepentingan bersama untuk mengekalkan sistem interaksi melalui peraturan, undang-undang dan institusi-institusi berkenaan. Sungguhpun setiap negara mempunyai kepentingan dan keutamaan yang berbeza, namun kesedaran terhadap kepentingan bersama akan dapat menyatukan mereka (Holsti 2009, 131). Rajah 1 menggambarkan keadaan yang dinyatakan. 


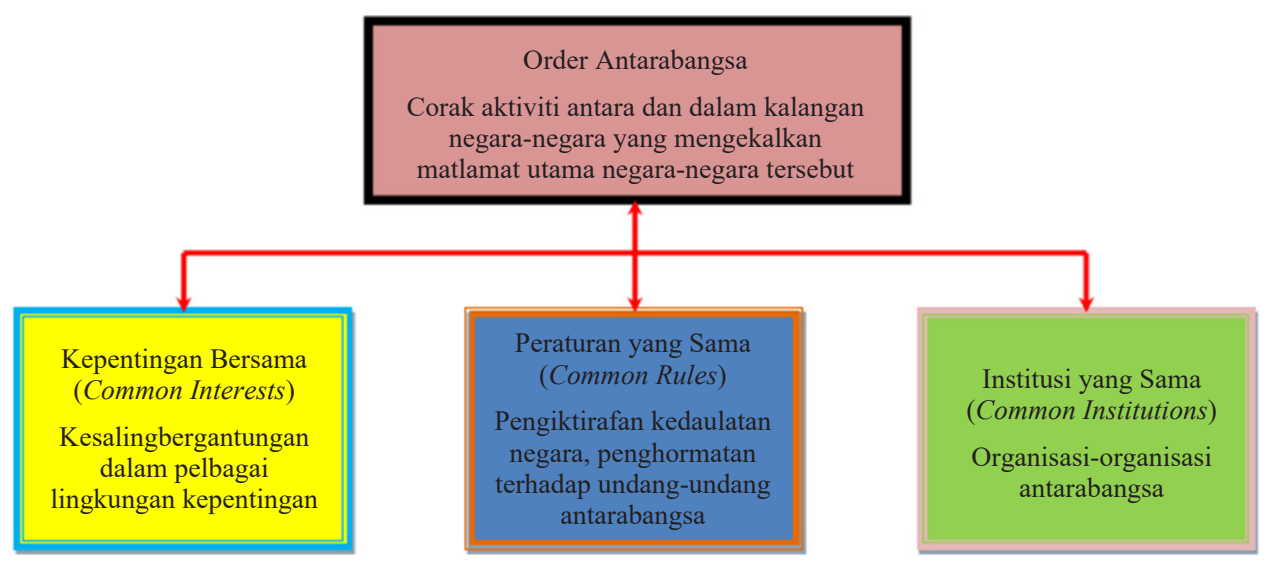

Rajah 1. Order antarabangsa (terjemahan penulis)

Sumber: Bull (1995)

\section{Faktor Pengeruh Hubungan Dua Hala}

\section{Hukuman mati terhadap pengedar dadah warga Australia}

Salah satu daripada peristiwa awal yang telah membawa kepada ketegangan antara Malaysia dengan Australia semasa pemerintahan Mahathir Mohamad adalah hukuman gantung terhadap dua warganegara Australia, Kevin Barlow dan Brian Chambers atas kesalahan mengedar dadah. Keputusan menjatuhkan hukuman gantung ini telah mendapat perhatian antarabangsa kerana Malaysia pada ketika itu baru sahaja melaksanakan hukuman gantung terhadap kes pengedar dadah. Malah, bekas Perdana Menteri Britain, Margaret Thatcher dan bekas Setiausaha Agung PBB, Perez de Cuellar telah mendesak Malaysia agar hukuman tersebut diringankan (The Age 1986a). Walaupun begitu, mahkamah di Malaysia telah memutuskan bahawa kedua-dua mereka bersalah dan hukuman mesti dijalankan. Selepas pelaksanaan hukuman pada tahun 1986, Perdana Menteri Australia ke-23, Bob Hawke, telah mengkritik Malaysia dan menganggap hukuman gantung tersebut adalah barbaric atau tidak bertamadun (Maniam 1986). Kenyataan Bob Hawke ini telah meninggalkan kesan negatif terhadap hubungan Malaysia dan Australia (Mauzy 1999, 340). Penggunaan istilah barbaric dilihat sebagai memperlekeh sistem kehakiman Malaysia dan maruah penduduk negara ini. Sekumpulan ahli politik Malaysia telah membuat bantahan terhadap Australia kerana memperkecilkan undang-undang negara dan menganggap hukuman mati tidak lagi relevan pada zaman ini (The Age 1986b). 
Dalam pada itu, kes penggantungan dua rakyat Australia ini juga telah menimbulkan persoalan tentang imej hak asasi manusia di Malaysia kerana dianggap tidak menghormati prinsip tersebut. Namun demikian, bagi Mahathir, isu pengedaran dadah merupakan satu perkara yang amat serius dan boleh mengancam keselamatan negara. Masalah pengedaran dadah di Malaysia dan rantau Asia Tenggara amnya telah berada pada tahap kritikal dan memerlukan penguatkuasaan hukuman yang ketat. Akan tetapi, perkara ini sukar diterima oleh pihak luar kerana mereka tidak memahami ancaman yang dihadapi oleh Malaysia berkenaan dengan masalah dadah (Gunn 2000, 115). Susulan daripada suasana tegang ini, Menteri Luar Australia, Gareth Evans telah menyampaikan permohonan maaf bagi pihak Bob Hawke kepada Mahathir. Namun demikian, tindakan Menteri Luar tersebut dikritik oleh kebanyakan media Australia kerana dilihat terlalu bertolak ansur dengan prinsip Australia dalam mempertahankan keselamatan warganya di luar negara (The Age 1991a). Kes penggantungan Barlow dan Chambers ini dianggap sebagai titik tolak bermulanya situasi tegang berterusan antara kedua-dua negara semasa era Mahathir.

\section{Kontroversi penayangan drama Embassy}

Isu kontroversi kedua yang merencatkan hubungan dua hala ialah berkait rapat dengan penayangan siri drama bertajuk Embassy di Australia pada awal tahun 1990. Drama tersebut menceritakan khayalan misi kedutaan Australia di sebuah negara Islam bermasyarakat majmuk bernama Ragaan di rantau Asia Tenggara yang terletak di utara Singapura dan selatan Thailand. Bayangan ini jelas sekali ditujukan kepada Malaysia (Camilleri 2001, 107).

Drama Embassy menggambarkan negara Ragaan dari sudut negatif. Sama ada kebetulan ataupun tidak, Malaysia pada masa itu juga dikritik hebat oleh banyak pihak berkenaan pembalakan haram, terutamanya di Sarawak. Mahathir menganggap drama tersebut diperalatkan untuk mencemar negara ini yang seakan tidak mematuhi perundangan alam sekitar antarabangsa dan ini boleh menjejaskan keyakinan pelabur luar terhadap Malaysia. Berikutan itu, Malaysia membekukan beberapa projek kerjasama dengan Australia (Schofield 2000, 108; Camilleri 2001, 109-110).

Seterusnya, perkara yang lebih memburukkan keadaan adalah penyiaran drama tersebut oleh Australian Broadcasting Corporation (ABC) yang dimiliki oleh kerajaan Australia. Secara tidak langsung, kerajaan Australia dianggap terlibat dengan drama tersebut. Sungguhpun begitu, kerajaan Australia segera menafikan penglibatannya dalam drama Embassy (Byrnes 1994, 176). Sebagai tindak balas, media di Malaysia khususnya TV3 telah menyiarkan beberapa dokumentari 
berkenaan Australia sebagai reaksi terhadap Embassy. Dokumentari The Ugly Face of Australia umpamanya memaparkan dasar diskriminasi kerajaan Australia terhadap penduduk asalnya dan orang Asia. Pembabitan Malaysia dalam dokumentari berkenaan, walaupun demikian, telah dinafikan oleh bekas Timbalan Menteri Luar pada waktu itu, Abdullah Fadzil Che Wan (New Straits Times 1991). Akibat daripada isu serangan timbal-balik ini, media kedua-dua negara dilihat terus memainkan elemen satire (sindir-menyindir) antara satu dengan yang lain sehingga meletakkan situasi hubungan dua hala bertambah kritikal apabila wujud ura-ura untuk menggantung kerjasama pertahanan antara mereka. Kenyataan ini dipetik daripada Pejabat Pesuruhjaya Tinggi Malaysia di Australia yang menyatakan bahawa adalah tidak mustahil perkara tersebut boleh berlaku (The Age 1990).

Bagi menjernihkan semula suasana, pentadbiran Canberra telah menghantar surat permohonan maaf Bob Hawke melalui Menteri Luarnya, Gareth Evans di Kuala Lumpur. Namun, penghantaran surat tersebut dinafikan oleh Evans (berdasarkan temu bual dengan Mahathir Mohamad pada 12 Mac 2014). ${ }^{2}$ Beberapa bulan kemudian, Malaysia menunjukkan kesediaan untuk memulihkan semula hubungannya dengan Australia. Akhirnya pada tahun 1991 dalam Persidangan Negara-Negara Komanwel (CHOGM) di Harare, Zimbabwe, kedua-dua pemimpin bersetuju untuk lebih berhati-hati dalam membuat sebarang kenyataan terhadap mana-mana laporan media yang tidak tepat (Searle 1996, 60). Pendirian ini tidak disenangi oleh sebahagian besar rakyat dan media Australia kerana dianggap tidak tegas mempertahankan prinsip dan amalan media bebas di Australia (Barker 1991, 11). Namun, perkembangan tersebut amat penting dalam memelihara hubungan bilateral agar sektor pelaburan dan perdagangan antara Australia dan Malaysia tidak terjejas (The Age 1991b).

\section{Filem Turtle Beach}

Isu kontroversi yang ketiga pula berkaitan dengan sebuah filem bertajuk Turtle Beach bersandarkan kepada novel karya Blanche d'Alpuget, penulis Australia. Penulis adalah bekas isteri kepada seorang diplomat yang pernah bertugas di Indonesia dan Malaysia serta kemudiannya menjadi isteri kepada Bob Hawke, Perdana Menteri Australia. Aspek kontroversi filem ini berkait rapat dengan salah satu babak yang telah diubah suai daripada cerita asal novel iaitu tentang perlakuan kejam yang dilakukan oleh beberapa orang penduduk kampung di Malaysia dengan membunuh sekumpulan pelarian Vietnam yang mencari perlindungan di Pulau Bidong, Terengganu (Camilleri 2001, 126). 
Aspek kekejaman dalam filem ini telah dikecam oleh Malaysia kerana filem tersebut tidak menggambarkan perkara yang sebenar. Oleh itu, Malaysia telah merujuk isu filem tersebut kepada Pertubuhan Bangsa-Bangsa Bersatu Bagi Pelarian (United Nations High Commissioner for Refugees, UNHCR). UNHCR telah memberikan penjelasan bahawa kejadian seperti yang ditunjukkan di dalam filem berkenaan tidak pernah berlaku di Malaysia (ibid.). Bagi menenteramkan keadaan, tiga minggu sebelum filem tersebut ditayangkan, kerajaan Australia telah bertindak awal dengan menyatakan bahawa ia tidak terlibat dalam pembikinan filem Turtle Beach (The Age 1992a).

Kecewa dengan perkembangan tersebut, Mahathir menyatakan bahawa adalah sukar untuk Malaysia berlaku baik terhadap Australia kerana negara ini seringkali gagal untuk konsisten memelihara hubungan baik antara dua negara. Walaupun Menteri Luar Australia menjelaskan bahawa filem itu adalah rekaan semata-mata, namun Mahathir menganggap Australia telah bertindak melebihi sempadan kebebasan media dengan memberi imej negatif tentang Malaysia (Australian 1992, 3). Menteri Luar Malaysia ketika itu, Abdullah Ahmad Badawi dan timbalannya, Abdul Fadzil Che Wan turut melahirkan kekecewaan mereka kerana penayangan filem tersebut dianggap sebagai satu penipuan besar dan boleh meretakkan hubungan yang baru sahaja pulih akibat daripada isu-isu terdahulu (Camilleri 2001, 127; The Age 1992b, 4). Walaupun begitu, kenyataan penafian segera pembabitan Australia dengan filem tersebut telah berjaya meredakan sedikit suhu ketegangan.

\section{Paul Keating dan recalcitrant}

Selanjutnya, isu ungkapan recalcitrant (keras kepala) oleh Paul Keating, Perdana Menteri Australia ke-24 terhadap keengganan Mahathir untuk hadir ke mesyuarat Kerjasama Ekonomi Asia Pasifik (Asia-Pacific Economic Cooperation, APEC) di Amerika Syarikat pada tahun 1993 atas undangan Presiden Amerika Syarikat, Bill Clinton (Searle 1996, 61; Camilleri 2001, 141). Isu ini boleh dianggap sebagai isu yang paling kontroversi dalam tradisi hubungan Malaysia-Australia. Pada dasarnya, APEC adalah inisiatif Australia untuk memperluas kerjasama ekonomi dalam kalangan negara Asia Pasifik yang terdiri dari beberapa negara maju seperti Amerika Syarikat, Jepun dan Kanada serta negara membangun yang lain termasuklah Malaysia (Johnson 1993, 55).

Mahathir beranggapan bahawa APEC tidak mampu untuk memanfaatkan kesemua ahlinya memandangkan ia didominasi oleh negara-negara maju seperti Amerika Syarikat dan kuasa ekonomi yang lain. Oleh itu, beliau mencadangkan penubuhan Kumpulan Perundingan Ekonomi Asia Timur (East Asia Economic 
Group, EAEG) yang kemudiannya menjadi Kaukus Ekonomi Asia Timur (East Asia Economic Caucus, EAEC) menjelang akhir tahun 1990. EAEG/EAEC diilhamkan agar dapat mempromosikan jaringan antara negara ASEAN dengan ekonomi negara Asia Timur. Berbeza dengan APEC, EAEG/EAEC tidak melibatkan Amerika Syarikat, Kanada dan Australia. Malangnya, sambutan terhadap cadangan ini adalah malap (MacIntyre 1993, 265).

Berikutan kritikan pedas "keras kepala" oleh Keating terhadap Mahathir, perkara ini telah menjadi satu isu yang hangat di Malaysia. Hal ini kerana isu recalcitrant telah mengeruhkan semula hubungan dua hala (Searle 1996). Australia cuba menjelaskan kepada Malaysia bahawa kenyataan Keating adalah tanpa niat disebabkan oleh desakan para wartawan yang bertanya tentang keengganan Mahathir untuk hadir dalam mesyuarat APEC tersebut. Penjelasan Australia tidak diterima oleh Mahathir kerana menganggap penggunaan istilah recalcitrant sebagai serangan peribadi terhadapnya. Akibat daripada ini, kerajaan Malaysia telah bertindak balas dengan mengenakan syarat yang lebih ketat terhadap kesemua program televisyen, filem dan iklan yang dihasilkan oleh Australia bagi sebarang tayangan komersial di negara ini (temu bual bersama Mahathir Mohamad, 12 Mac 2014; Paul 1998). Rentetan daripada insiden ini juga, akhbarakhbar Australia dan Malaysia saling berbalas kritikan dan kecaman. Sebagai contoh, akhbar The Age Australia mengkritik Mahathir kerana ingin bersaing dengan Australia, tidak bersikap rasional, mementingkan diri dan mempunyai elemen rasisme (Baker 1993, 15).

Akhbar Malaysia pula telah menjadikan perbalahan Keating dan Mahathir sebagai tajuk utama seperti "Australia Tidak Beradab: Mahathir" (Berita Harian 1993a, 1), "Disgusted with the Uncouth Remarks of Australian PM" (New Straits Times 1993a, 13), "Enggan Menghadiri Sidang APEC: Mahathir Tidak Kesal" (Berita Harian 1993b, 1), "Keating's Insensitivity to Blame" (New Straits Times 1993b) dan "Straight Talking Versus Offensive Outburst" (New Straits Times 1993c, 13) (Camilleri 2001, 144-145). Rata-rata akhbar Malaysia mencemuh Keating kerana tidak peka dalam menjaga kepentingan hubungan dua hala (New Straits Times 1993b).

Dalam pada itu, Menteri Luar Australia, Gareth Evans cuba menjernihkan suasana dengan mengecam para wartawan yang terlalu mendesak Keating sehingga suatu kenyataan pedas dibuat terhadap Mahathir (Australian 1993, 2). Malangnya, situasi ini menjadi semakin parah apabila Keating enggan membuat permohonan maaf kepada Mahathir (Baker 1993, 1). Disebabkan desakan yang berterusan daripada komuniti perniagaan Australia, pentadbiran Canberra akhirnya telah mengutus sepucuk surat kepada kerajaan Malaysia bagi 
mententeramkan keadaan. Namun begitu, sama ada Keating sendiri yang telah memohon maaf kepada Malaysia ataupun dari pihak lain adalah tidak pasti kerana isi kandungan surat tersebut tidak pernah ditunjukkan kepada umum (Camilleri 2001, 156). Sementara itu, berdasarkan temu bual penulis dengan Mahathir, pemimpin ulung ini menyatakan bahawa Australia tidak pernah membuat permohonan maaf kepada Malaysia sama ada secara rasmi ataupun peribadi (temu bual bersama Mahathir Mohamad pada 12 Mac 2014).

\section{Isu pemecatan Anwar Ibrahim}

Isu yang terakhir adalah bersangkut-paut dengan pemecatan bekas Timbalan Perdana Menteri Malaysia, Anwar Ibrahim. Penyingkiran Anwar daripada kabinet kerajaan bukan sahaja telah mencetuskan krisis politik dalaman tetapi juga telah menarik perhatian antarabangsa terhadap Malaysia, termasuklah Australia. Kronologi isu pemecatan Anwar Ibrahim bermula dengan krisis ekonomi Asia Tenggara yang berlaku pada tahun 1997. Pada awalnya, kerajaan yakin bahawa Malaysia akan terlindung daripada krisis ekonomi ini memandangkan asas ekonomi negara yang kukuh berikutan pertumbuhan memberangsangkan dengan kadar $8 \%$ selama 10 tahun berturut-turut. Malangnya, Malaysia tidak terkecuali menjadi mangsa kegawatan ekonomi tersebut apabila nilai ringgit dan pasaran saham telah jatuh mendadak (Mahathir Mohamad 2000, 7). Bagi mengatasi kegawatan ekonomi yang melanda, Mahathir telah menolak bantuan kewangan International Monetary Fund (IMF) kerana falsafah dan kaedah badan kewangan ini dianggap tidak sesuai dengan ekosistem ekonomi negara. Bagi Mahathir, kemajuan ekonomi bukanlah semata-mata berdasarkan kepada keluaran dalam negara kasar (KDNK) tetapi juga agihan ekonomi yang seimbang kepada semua etnik di Malaysia (ibid.).

Walaupun demikian, natijah isu pemecatan Anwar Ibrahim telah mencetuskan protes reformasi jalanan sehingga mendapat perhatian pihak luar, termasuklah Australia. Ramai pemerhati politik berpandangan bahawa pemecatan Anwar Ibrahim berunsur konspirasi politik bagi melindungi salah laku kerajaan dalam menangani krisis ekonomi yang melanda, terutamanya melibatkan jaminan (bail-out) terhadap pihak-pihak tertentu (Skehan 1998, 11).

Dari perspektif Australia, Anwar Ibrahim dilihat sebagai bakal Perdana Menteri Malaysia yang boleh merapatkan lagi hubungan dua hala dan mampu melakukan reformasi sistem kehakiman, hak asasi manusia dan kebebasan media. Oleh itu, Australia menerusi John Howard, Perdana Menteri Australia ke-25, telah membidas isu pemecatan Anwar Ibrahim dengan menggambarkan Malaysia bakal beralih ke arah pemerintahan kuku besi (The Age 1998a). Australia juga 
mengkritik dasar kawalan modal Mahathir yang dianggap kurang efektif dalam menangani kegawatan ekonomi kerana dasar tersebut dilihat tidak menggalakkan pelabur asing datang ke Malaysia (The Australian Financial Review 1998, 16).

Bagi menghadapi kritikan ini, Mahathir telah menyelar tindakan media asing yang sering memberikan gambaran yang tidak tepat tentang Malaysia. Menurut Mahathir, ramai pihak luar menyokong Anwar kerana dilihat mampu memenuhi apa yang mereka mahu Malaysia lakukan. Sekiranya Malaysia mengambil tindakan undang-undang terhadap rakyatnya, kerajaan akan dituduh mempunyai motif konspirasi tertentu (The Age 1998b, 16). Berkenaan kenyataan panas Howard, Malaysia telah menghantar sepucuk surat kepada Pesuruhjaya Tinggi Australia di Kuala Lumpur sebagai protes diplomatik bahawa kenyataan Howard adalah tidak berasas dan menunjukkan salah interpretasi terhadap sistem perundangan dan politik di Malaysia (BBC News 1998a).

Malangnya, bantahan diplomatik Malaysia terus diketepikan Australia. Semasa Kuala Lumpur menjadi tuan rumah bagi Persidangan APEC pada tahun 1998, Howard sekali lagi membangkitkan isu Anwar Ibrahim semasa bertemu dengan Mahathir sambil memaklumkan bahawa Menteri Luar Australia juga telah bertemu dengan isteri Anwar Ibrahim (BBC News 1998b). Melalui keadaan tersebut, dapat dilihat bahawa isu ini telah menimbulkan ketegangan antara kedua-dua negara. Tindakan Australia dianggap mencampuri hal ehwal dalaman Malaysia dan memberi mesej kepada Mahathir bahawa kepimpinan Howard dilihat seakan lebih cenderung kepada politik Anwar Ibrahim.

\section{Elemen-Elemen Utama yang Memperkuat Faktor Pengeruh}

Daripada perbincangan yang dibuat berkenaan dengan siri kontroversi Malaysia dan Australia, boleh dikatakan bahawa kebanyakan keadaan tersebut seolah-olah berpunca daripada tindakan pihak Australia sendiri terhadap corak pentadbiran Mahathir Mohamad. Bermula daripada isu barbaric sehinggalah pemecatan Anwar Ibrahim, jelas menunjukkan bahawa Malaysia cuba untuk mempertahankan pendirian dan menjelaskan keadaan sebenar yang berlaku. Namun demikian, Australia memilih untuk memberi reaksi berbeza sehingga mewujudkan situasi ketegangan dalam hubungan dua hala seperti dalam penjelasan berikut.

\section{Sikap kurang peka pemimpin Australia}

Seperti yang dinyatakan sebelum ini, sebahagian besar daripada kesemua isu kontroversi yang berlaku dicetuskan oleh Australia dengan melibatkan tiga orang pemimpin nombor satu negara tersebut akibat daripada kritikan mereka terhadap 
tindakan yang dilaksanakan oleh Malaysia. Bermula daripada Bob Hawke (1983-1991) dalam kes jenayah pengedaran dadah, penayangan drama Embassy dan filem Turtle Beach, Paul Keating (1991-1996) dengan komen "keras kepala" terhadap Mahathir sehinggalah John Howard (1996-2007) dalam kes Anwar Ibrahim. Bagi menangani isu-isu tersebut, Malaysia bertindak tegas mempertahankan pendirian negara agar masyarakat antarabangsa mendapat gambaran yang lebih tepat tentang perkara yang telah berlaku.

Tanpa dinafikan bahawa penglibatan secara langsung tiga perdana menteri Australia dalam tiga insiden tersebut telah menyebabkan hubungan Kuala Lumpur dan Canberra agak goyah. Ketiga-tiga pemimpin Australia ini secara langsung telah melontarkan kritikan terhadap isu-isu yang boleh merencatkan hubungan baik yang terjalin sekian lama. Dengan demikian, wujud tiga persoalan penting: (1) Adakah Hawke akan mempertikai sistem perundangan Malaysia sekiranya Barlow dan Chambers bukan warganegara Australia?, (2) Adakah Keating tidak akan mengatakan Mahathir sebagai 'keras kepala' sekiranya pemimpin Malaysia ini hadir mesyuarat APEC yang pertama? dan (3) Sekiranya Timbalan Perdana Menteri yang terlibat bukanlah Anwar Ibrahim, adakah Howard akan campur tangan dalam politik Malaysia?. Ketiga-tiga persoalan ini sememangnya sukar untuk dijawab namun pada hakikatnya, kritikan telah dibuat oleh kerajaan Australia dan secara tidak langsung telah menyebabkan situasi yang agak tegang berlaku.

\section{Peranan media Australia}

Malaysia dan Mahathir sering dikritik oleh media Barat, termasuk Australia berkenaan dengan pelbagai isu terutamanya yang berkait rapat dengan perundangan domestik Malaysia seperti Akta Keselamatan Dalam Negeri, penentangan Mahathir terhadap usaha Australia mengetuai pertubuhan kerjasama ekonomi serantau, kes pemecatan Anwar Ibrahim dan lain-lain lagi. Menurut Camilleri (2001), dalam kes penggantungan Barlow dan Chambers, peranan yang dimainkan oleh media Australia amat ketara. Tidak banyak penjelasan maklumat yang diberikan oleh media Australia berkenaan masalah dadah di Malaysia kepada rakyat mereka. Dengan itu, keadaan ini boleh menimbulkan suasana salah faham tentang sistem perundangan di Malaysia kerana tidak memperoleh maklumat yang tepat tentang jenayah dadah yang dilakukan oleh warga Australia tersebut sehingga membawa kepada hukuman gantung.

Perkara selanjutnya ialah isu tayangan drama Embassy dan filem Turtle Beach yang merupakan dua produk media Australia. Camilleri (2001) menyatakan bahawa kedua-dua drama dan filem tersebut bersifat amat provokatif kerana 
motif sebenar penayangan drama dan filem tersebut adalah tidak diketahui. Dengan itu, rakyat Australia berkemungkinan akan berasa keliru sama ada drama dan filem berkenaan bersifat fakta atau khayalan semata-mata. Senario ini tidak akan dapat memberi manfaat kepada rakyat Australia dan usaha berterusan perlu dibuat oleh kedua-dua negara bagi menyalurkan maklumat yang lebih tepat sama ada dalam bentuk dokumentari khas atau kenyataan bertulis secara rasmi.

Tidak dinafikan bahawa terdapat perbezaan amalan dan etika antara media Australia dengan Malaysia dalam melaporkan sesuatu isu. Perbezaan ini sememangnya mempengaruhi corak interaksi antara kerajaan Malaysia dengan Australia (Knight 2000, 3-4). Mustafa (2000) pula berpendapat bahawa fungsi media di Malaysia adalah untuk membantu kerajaan menyampaikan maklumat tentang dasar-dasar tertentu demi kebaikan rakyat. Berbeza dengan Australia, amalan media di negara tersebut menekankan budaya profesional Barat yang lebih bersifat liberal dan bebas. Sebarang kritikan terhadap kerajaan, badan korporat ataupun personaliti berprofil tinggi adalah sesuatu yang lazim dan tidak dianggap bertentangan dengan etika dan sistem perundangan media (Knight 2000). Hal ini jelas menunjukkan bahawa wujud perbezaan darjah keterbukaan budaya media Australia dan Malaysia yang berpotensi mencetuskan situasi salah faham. Oleh itu, kedua-dua negara perlu lebih berinteraksi terutamanya dalam konteks "budaya dan media" agar dapat mengelakkan sebarang pergeseran berpunca daripada sesuatu laporan media.

\section{Pertembungan "nilai" antara Timur dengan Barat}

Sesuatu yang menarik untuk diamati bahawa kekeruhan hubungan antara Malaysia dan Australia juga turut melibatkan elemen "nilai" Timur dan Barat. Seperti diketahui umum, Mahathir sememangnya terkenal dengan pendirian kritisnya terhadap nilai-nilai Barat, termasuklah Australia. Maka, tidak hairanlah sekiranya Mahathir sering dianggap sebagai seorang yang rasis, diktator, anti-Yahudi mahupun keras kepala oleh dunia Barat.

Searle (1996) beranggapan bahawa wujud elemen persaingan nilai antara Timur dengan Barat dalam konteks hubungan Malaysia dan Australia. Dengan wujudnya elemen ini, timbul satu persoalan iaitu pihak manakah yang lebih "Timur" sifatnya? Kedua-dua negara dilihat seolah-olah sering bersaing antara satu dengan yang lain untuk menjadi "ketua" di rantau ini. Mahathir sering mempersoalkan identiti negara Australia dengan acapkali mempertikai penglibatannya di Asia seperti peranan dominan Australia dalam isu kemerdekaan Timor Leste dan lain-lain lagi (Kelly 2010, 171). 
Sungguhpun dari segi geografi Australia masih terletak di hujung rantau Asia, namun Mahathir melihat Australia sebagai sebahagian daripada Barat. Situasi ini disokong oleh sejarah Australia itu sendiri seperti dasar White Australia yang menghalang kemasukan orang bukan berkulit putih ke negara tersebut. Namun, hal ini tidak bermaksud bahawa Mahathir adalah anti-Barat. Perkara yang dikritik oleh Mahathir adalah berkenaan dengan nilai dan etika Barat yang ingin dipaksa masuk ke semua negara di dunia termasuklah Asia. Tambahan pula, sikap Barat yang menganggap mereka sentiasa betul dan lebih hebat daripada yang lain adalah sesuatu yang tidak dapat diterima dengan mudah (Mahathir Mohamad 1999, 68). Memandangkan Australia menganggap ia sebahagian daripada Barat dan tindakannya sering berpihak kepada Barat, maka sukar bagi keduadua negara untuk bersetuju dalam isu-isu yang melibatkan nilai tertentu kerana masing-masing mempunyai pandangan yang berbeza.

\section{Peranan alumni Australia warga Malaysia}

Selanjutnya pula, salah satu daripada faktor yang dikenal pasti menyumbang kepada ketegangan hubungan antara Malaysia dengan Australia adalah peranan yang dimainkan oleh bekas-bekas pelajar (alumni) Malaysia yang melanjutkan pelajaran mereka ke Australia dan terus menetap di negara tersebut. Situasi ini dipercayai disebabkan oleh peluang kerjaya yang menarik di Australia telah membuatkan mereka enggan untuk kembali ke tanah air sebaliknya terus menetap di sana.

Sebahagian besar daripada para pelajar tersebut adalah dalam kalangan mereka yang tidak mendapat biasiswa atau bantuan kewangan daripada pihak kerajaan dan terpaksa melanjutkan pelajaran mereka dengan bekerja sendiri ataupun dengan pembiayaan ahli keluarga terdekat. Justeru, setelah mereka mendapat peluang yang lebih baik di Australia, mereka enggan pulang ke Malaysia dan mula memberikan gambaran negatif berkenaan dasar-dasar kerajaan Malaysia kepada rakyat mahupun kerajaan Australia (Hugo 2011). Hal yang sama turut diutarakan dalam temu bual dengan Anthony Milner pada 8 April 2010. ${ }^{3}$ Secara amnya, Mahathir menyetujui kewujudan faktor ini dengan menyatakan bahawa kebanyakan daripada bekas pelajar yang enggan kembali ke Malaysia adalah mereka yang tidak berpuas hati dengan beberapa dasar kerajaan Malaysia seperti Dasar Ekonomi Baru (DEB). Menurut Mahathir, pandangan yang sedemikian adalah tidak berasas kerana mereka tidak memahami objektif sebenar DEB. Semenjak diperkenalkan pada tahun 1970, usaha ini telah berjaya (walaupun tidak sepenuhnya) mengagihkan kekayaan negara secara menyeluruh kepada rakyat dan cuba menyasarkan $30 \%$ pemilikan ekuiti oleh kaum bumiputera. Dianggarkan pada tahun 2017, pemilikan ekuiti bumiputera baru 
sahaja menghampiri ke angka 25\% (Berita Harian 2017). Oleh demikian, adalah jelas bahawa rakyat Malaysia yang merupakan bekas pelajar yang menuntut di Australia dan terus berkhidmat di negara tersebut berpotensi untuk memberikan gambaran yang tidak tepat berkenaan dasar kerajaan Malaysia bukan sahaja di Australia, malah mungkin di tempat yang lain.

\section{Faktor Pengukuh Hubungan Bilateral dari Perspektif Teori English School}

Sungguhpun terdapatnya beberapa faktor pengeruh yang boleh menjejaskan hubungan Malaysia dan Australia namun hubungan diplomatik kedua-dua negara tetap utuh sepanjang era Mahathir Mohamad. Sewaktu sesi temu bual dengan Mahathir, pemimpin tersebut menyatakan bahawa sebarang cadangan untuk memutuskan hubungan diplomatik dengan Australia adalah tidak bijaksana (tanpa menafikan bahawa beliau pernah menerima saranan agar memutuskan hubungan dengan Australia) bahkan akan merugikan kedua-dua belah pihak. Hal ini kerana kedua-dua negara telah bekerjasama sekian lama dalam pelbagai bidang seperti pendidikan, pelancongan, perniagaan, pertahanan dan interaksi sosial antara warga Malaysia dengan Australia (New Straits Times 2003).

Berdasarkan perbincangan perihal pasang surut hubungan antara Malaysia dan Australia era Mahathir, ternyata sungguhpun adakalanya berlaku ketegangan disebabkan oleh isu-isu tertentu, namun hubungan dua hala tetap utuh. Persoalannya, apakah elemen-elemen yang memelihara keutuhan hubungan Malaysia-Australia walaupun dilanda pelbagai cabaran? Analisis persoalan ini dapat dijelaskan dengan baik melalui teori English School berdasarkan konsep masyarakat antarabangsa dan order antarabangsa. Teori ini mendapat perhatian yang meluas dalam kalangan para sarjana Hubungan Antarabangsa kerana dianggap sebagai alternatif kepada teori-teori utama iaitu Realisme, Liberalisme, Neo-Marxisme (Neo-Marxism) dan Social Constructivism. Hal ini kerana teori English School mengambil pendekatan pertengahan antara teori Realisme dan Idealisme/Liberalisme. Antara tokoh pendukung teori ini termasuklah Charles Manning, Martin Wight, Herbert Butterfield, Hedley Bull, Barry Buzan, Tim Dunne dan Andrew Linklater.

Fenomena utama yang dikaji oleh para sarjana English School adalah bagaimana fenomena "order" atau "order antarabangsa" (Bull 1995) boleh wujud dalam sistem antarabangsa yang tidak mempunyai kerajaan dunia bagi memantau hubungan antara negara? Order antarabangsa yang dimaksudkan oleh Bull adalah corak interaksi antara negara yang mengekalkan objektif utama ahli dalam masyarakat antarabangsa. Keadaan ini termasuklah hubungan diplomasi, perdagangan, pelaburan dan lain-lain. Malah, order lebih ketara terjelma pada 
peringkat antarabangsa berbanding politik dalaman sesebuah negara yang sering dicorakkan oleh konflik dalaman (Wilson 2013). Oleh yang demikian, Bull menghujahkan bahawa fenomena order terhasil daripada wujudnya tiga elemen iaitu perkongsian kepentingan yang sama, perkongsian peraturan atau undangundang yang sama pada peringkat antarabangsa dan perkongsian institusi yang sama. Dalam erti kata lain, persamaan kepentingan (interest), peraturan (rules) dan institusi (institutions) membantu mewujudkan fenomena order pada peringkat antarabangsa yang menurut neo-realisme bersifat anarki. Dengan itu, teori English School dilihat dapat menjelaskan dengan baik berkenaan cara order atau kestabilan hubungan antara Malaysia dengan Australia dapat dikekalkan sungguhpun berdepan dengan pelbagai kontroversi semasa pemerintahan Mahathir. Interaksi antara kedua-dua negara ini dilihat menyamai gambaran berkenaan masyarakat antarabangsa yang membantu kepada order atau kestabilan hubungan bilateral Malaysia-Australia secara keseluruhan.

Sekiranya dilihat daripada perspektif kepentingan bersama, kedua-dua negara berkongsi banyak perkara yang membawa manfaat bersama. Sebagai contoh, kerjasama pertahanan melalui FPDA dan Malaysia-Australia Joint Defence Programme (MAJDP) terus berkembang sungguhpun ada ketikanya hubungan politik antara kedua-dua negara tegang. Kerjasama pertahanan melalui aktiviti latihan ketenteraan bersama dalam memantapkan keselamatan di rantau ini menjadi salah satu elemen pengukuh dalam hubungan bilateral. Malah, adalah tidak keterlaluan untuk mengatakan bahawa kerjasama pertahanan antara Malaysia dan Australia merupakan elemen komponen yang amat penting dalam mengukuhkan hubungan kedua-dua negara (Snyder 2015).

Kepentingan bersama dalam konteks ekonomi turut menyumbang kepada kestabilan hubungan dua hala. Malaysia dan Australia merupakan rakan ekonomi yang penting. Kerjasama ekonomi khasnya dalam bentuk pelaburan, perdagangan, pelancongan dan kerjasama pendidikan turut menyumbang kepada pertumbuhan ekonomi.

Banyak manfaat telah dicapai khususnya dalam bidang ekonomi dan perdagangan antara kedua-dua negara. Aktiviti eksport dan import umpamanya telah meningkat dengan begitu pesat kecuali semasa berlakunya krisis ekonomi Asia yang bermula pada tahun 1997. Namun begitu, bermula pada tahun 1998, aktiviti eksport dan import melibatkan kedua-dua negara telah kembali berkembang (rujuk Rajah 2).

Sehingga penghujung tahun 2003, Malaysia merupakan rakan dagang ketiga terbesar bagi Australia dalam kalangan negara ASEAN dan ke-11 di dunia. Bagi Malaysia pula, Australia merupakan pasaran eksport ke-12 terbesar 
(Australian Government, Department of Foreign Affairs and Trade 2005). Rajah 2 menunjukkan aktiviti perdagangan Malaysia-Australia bermula dari tahun 1981 sehingga 2003.

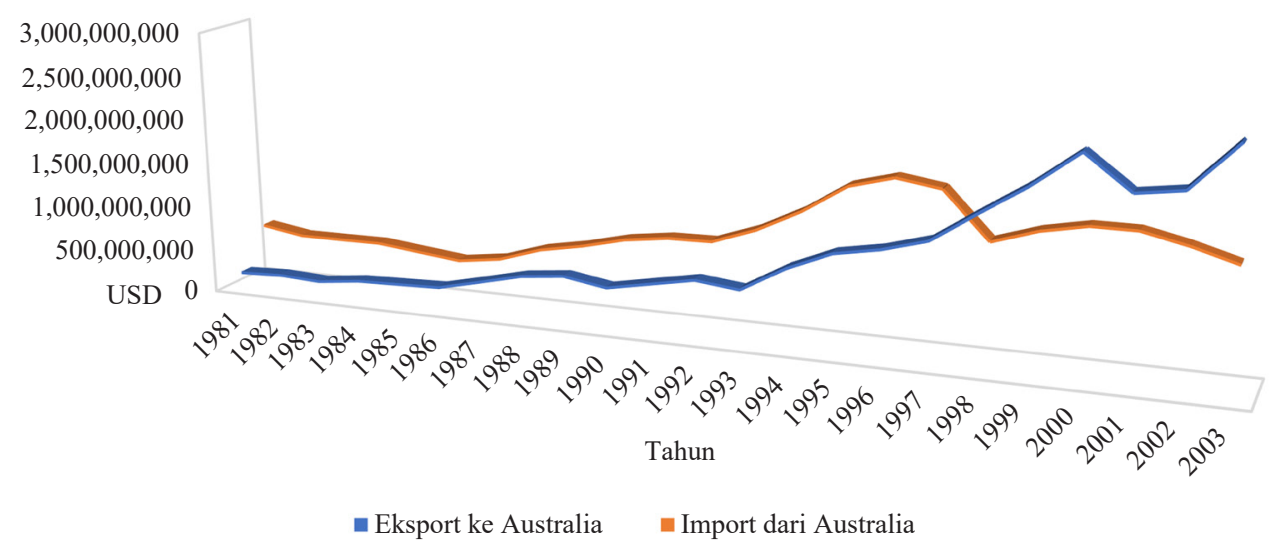

Rajah 2. Eksport dan import Malaysia-Australia, 1981-2003

Sumber: Data diubah suai daripada UNCOMTRADE (2020)

Analisis aktiviti perdagangan antara Malaysia dan Australia pada tahun-tahun 1980, 1990 dan 2000 menzahirkan peningkatan positif. Sebagai contoh, jumlah perdagangan antara kedua-dua negara telah melonjak dari USD800 juta pada tahun 1980 kepada USD1.3 bilion bagi tahun 1990 dan USD3.9 bilion pada tahun 2000. Peningkatan mendadak ini membuktikan bahawa ketegangan media politik antara kedua-dua negara tidak mempunyai kesan yang besar terhadap hubungan ekonomi kerana kepentingan bersama mengatasi perbezaan pandangan politik.

Selain itu, salah satu petunjuk ekonomi yang dapat membuktikan kekuatan ekonomi dalam konteks hubungan kedua-dua negara adalah melalui pelaburan langsung asing. Pelaburan langsung asing antara Malaysia dengan Australia semasa pemerintahan Mahathir terus menunjukkan peningkatan. Rajah 3 menunjukkan corak aliran pelaburan langsung Australia ke Malaysia dari tahun 1980 sehingga 1995 yang berkembang dengan kukuh. Nilai pelaburan langsung dari Australia dianggarkan hanya bernilai MYR9.1 juta pada tahun 1980. Menjelang tahun 1985, nilai tersebut telah meningkat $300 \%$ kepada MYR25.7 juta. Pada tahun 1990, nilai pelaburan langsung asing Australia ke Malaysia terus mencatat kenaikan daripada MYR54.3 juta kepada MYR139.5 juta pada tahun 1995 iaitu dua tahun sebelum berlakunya krisis mata wang Asia. Keadaan ini menunjukkan bahawa perkongsian kepentingan ekonomi membantu mengeratkan hubungan biarpun wujud ketegangan politik. 


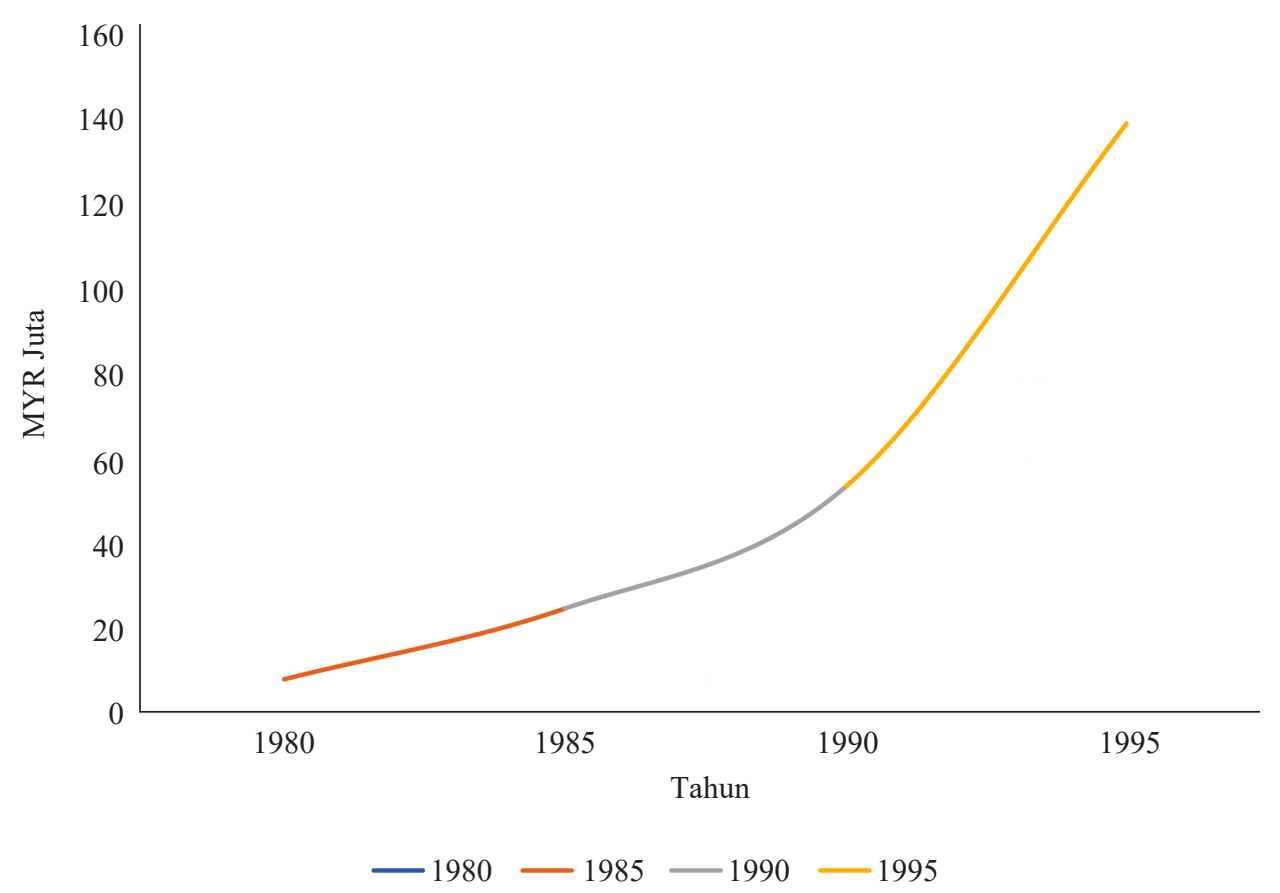

Rajah 3. Pelaburan langsung asing Australia ke Malaysia (MYR juta), 1980-1995 Sumber: Mohamed Ariff (2007)

Dalam pada itu, Malaysia dan Australia turut berkongsi beberapa peraturan atau undang-undang antarabangsa. Hal ini termasuklah kepatuhan terhadap pelbagai konvensyen dan undang-undang antarabangsa seperti Konvensyen PBB Mengenai Undang-Undang Laut (UNCLOS) 1982, undang-undang kemanusiaan antarabangsa, undang-undang perdagangan antarabangsa dan konvensyenkonvensyen yang melibatkan perubahan iklim antarabangsa. Salah satu contoh yang boleh dirujuk adalah penyelesaian pertikaian berkenaan undang-undang perdagangan antarabangsa. Pada tahun 1996, Malaysia bersama-sama dengan India, Thailand dan Pakistan telah membuat aduan kepada Pertubuhan Perdagangan Dunia (World Trade Organization, WTO) berkenaan larangan mengeksport udang dan produk-produk udang ke Amerika Syarikat. Negara-negara pengadu tersebut telah memohon agar sebuah panel ditubuhkan bagi menyelesaikan masalah berkenaan. Australia bersama beberapa negara lain telah menjadi pihak ketiga (mediator) dalam penyelesaian kes tersebut. Sungguhpun keputusan yang dikeluarkan pada tahun 2001 tidak memihak kepada negara-negara yang membuat aduan, kesediaan Australia menjadi pihak ketiga dalam kes tersebut membuktikan bahawa Kuala Lumpur dan Canberra mampu berkongsi sentimen yang sama dan telah menggunakan mekanisme undang-undang perdagangan antarabangsa melalui WTO untuk menyelesaikan kes tersebut (WTO 2001). Hal ini menjelaskan 
bahawa sekiranya Malaysia dan Australia menjadi sebahagian daripada ahli dalam masyarakat antarabangsa, maka sudah tentu order dapat dipertahankan sewaktu elemen seperti perkongsian peraturan yang sama pada peringkat antarabangsa dihormati.

Dalam konteks perkongsian institusi yang sama (common institutions), ternyata Malaysia dan Australia berkongsi keahlian dan aktif dalam pelbagai institusi antarabangsa. Hal ini termasuklah PBB, Pertubuhan Komanwel, WTO, APEC, Forum Serantau ASEAN (ARF) dan lain-lain lagi. Melalui perkongsian institusi dan kerjasama yang sama, sudah tentu kedua-dua negara arif betapa mereka mempunyai banyak persamaan dalam melestarikan kepentingan negara pada peringkat antarabangsa. Dengan itu, kepentingan bersama tersebut menjadi keutamaan mereka berbanding perbezaan yang wujud dan keadaan ini turut membantu dalam mengendurkan ketegangan politik yang berlaku. Sebagai contoh, pada tahun 1991, semasa Persidangan Pertubuhan Komanwel diadakan di Harare, Zimbabwe, kedua-dua kepemimpinan negara telah bersetuju untuk memulihkan hubungan dua hala akibat daripada kontroversi penayangan drama Embassy (Searle 1996, 60). Mereka turut bersepakat untuk mengelakkan sebarang campur tangan kerajaan masing-masing dalam mana-mana laporan media yang tidak tepat, yang boleh mengeruhkan hubungan diplomatik. Malangnya, Bob Hawke telah dikecam hebat oleh parti pembangkang di Australia sekembalinya daripada Harare akibat daripada tindakan diplomasi terhadap kepimpinan Mahathir (Zainudin 2008, 104).

Dalam erti kata yang lain, perkongsian dalam memelihara kepentingan (common interests), menghormati peraturan (common rules) dan menganggotai institusi yang sama (common institutions) telah berfungsi untuk menjadi nadi kepada masyarakat antarabangsa, maka order dan kestabilan dapat dipertahankan dalam hubungan bilateral kedua-dua negara. Sungguhpun adakalanya kepentingan lain bertembung dengan kepentingan nasional, negara-negara termasuklah Malaysia dan Australia sentiasa bersedia untuk bertolak ansur dan bersikap lebih terbuka bagi mencapai matlamat yang lebih besar (Burchill 2005, 155-170). Model yang dinyatakan dalam Rajah 4 dapat menjelaskan secara keseluruhan faktor terpenting (faktor pengeruh dan faktor pengukuh) dalam memaparkan keutuhan hubungan Malaysia dan Australia melalui pendekatan teori English School.

Berdasarkan Rajah 4, terdapat dua faktor utama yang mempengaruhi hubungan dua hala kedua-dua negara iaitu empat faktor pengeruh yang diwarnai oleh lima isu kontroversi dan faktor pengukuh yang diilustrasikan dalam konsep "order" melalui perkongsian tiga tema (common interests, common rules dan common institutions) dari perspektif teori English School. 


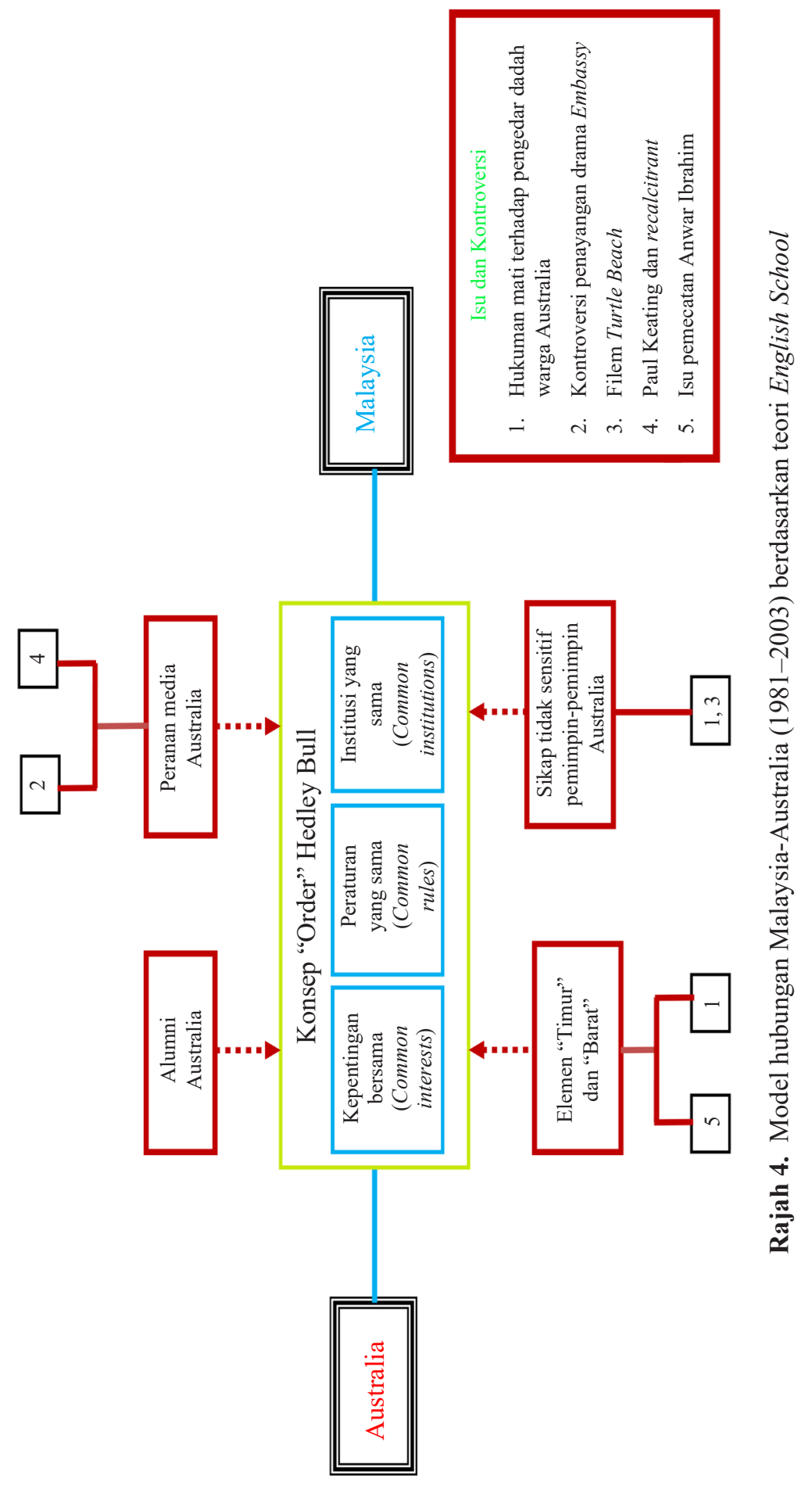




\section{Kesimpulan}

Hubungan kerajaan antara Malaysia dengan Australia semasa pentadbiran Mahathir Mohamad telah menunjukkan suasana tegang yang amat ketara. Keadaan ini berbeza dengan era sebelum Mahathir kerana pada ketika itu, hubungan pemimpin-pemimpin Malaysia dengan Australia adalah amat rapat. Australia menganggap Mahathir sebagai pengkritik yang agak kritikal dan bersifat kontroversial. Dalam kajian ini, penulis telah mengupas lima isu penting yang berfungsi sebagai faktor pengeruh dalam hubungan Malaysia dan Australia semasa era pemerintahan Mahathir. Jelas sekali, hukuman gantung terhadap Barlow dan Chambers, drama Embassy, filem Turtle Beach, isu recalcitrant dan pemecatan Anwar Ibrahim telah memberi cabaran besar terhadap hubungan Malaysia dan Australia.

Perlu juga disebutkan di sini bahawa Mahathir telah berhadapan dengan tiga era pemerintahan Perdana Menteri Australia iaitu Bob Hawke (1983-1991), Paul Keating (1991-1996) dan John Howard (1996-2007) yang kesemuanya mempunyai kepentingan berbeza dan berkehendakkan pendekatan bijaksana. Dalam semua isu yang telah dibincangkan, ternyata kesemua isu terbabit telah dimulakan dengan reaksi dan tindakan lebih terbuka pihak Australia dan dibalas secara defensif oleh kerajaan Malaysia bagi menjelaskan isu-isu yang ditimbulkan. Meskipun begitu, suasana ketegangan yang berlaku tidak sedikit pun menjejaskan hubungan baik dan kerjasama dalam pelbagai bidang yang memberi manfaat kepada kedua-dua negara. Interaksi perdagangan, jaringan pendidikan dan kerjasama pertahanan khasnya terus memperlihatkan perkembangan positif.

Keadaan yang stabil ini sebenarnya diteguhkan oleh faktor pengukuh berdasarkan kepada teori English School yang mementingkan elemen perkongsian dalam menjaga kepentingan bersama (common interests), mematuhi peraturan (common rules) dan menjadi ahli dalam institusi yang sama (common institutions). Ketiga-tiga elemen ini telah membuktikan kewujudan order dan seterusnya menyumbang kepada kestabilan serta keakraban hubungan antara Malaysia dengan Australia. Satu hal yang pasti ialah kedinamikan hubungan dua hala antara Malaysia dengan Australia pada saat berlakunya suasana kekeruhan membuktikan bahawa kepimpinan kedua-dua negara telah matang dalam mengutamakan kepentingan negara berbanding menghadam isu-isu kontroversi yang tidak mendatangkan sebarang manfaat. 


\section{Penghargaan}

Penyelidikan ini dibiayai sepenuhnya oleh Universiti Malaysia Sabah dan Kementerian Pengajian Tinggi Malaysia melalui Skim Latihan Akademik Bumiputera (SLAB/UMS2013). Penulis juga ingin merakamkan penghargaan kepada Australia-Malaysia Institute (AMI), Kementerian Hal Ehwal Luar dan Perdagangan Antarabangsa Australia (DFAT) atas dana penyelidikan pada tahun 2009.

\section{Nota}

1. Penulis ingin memaklumkan bahawa sebahagian daripada kandungan makalah ini telah diterbitkan dalam International Journal of Humanities and Social Science Invention (IJHSSI) Jilid 6, Isu 1, 2017 dengan judul "Malaysia-Australia Relations during Dr. Mahathir's Prime Ministership: A Consideration for the English School Perspective". Makalah ini lebih kepada olahan perbincangan deskriptif dan perbincangan ringkas dari sudut teori English School. Namun dalam makalah ini, skop dan analisis perbincangan lebih berpusat kepada penjelasan lebih komprehensif tentang faktor pengeruh (souring factor) dan faktor pengukuh (enduring factor) dalam ruang lingkup teori English School. Selain itu, beberapa jadual, model kajian dan rujukan baharu turut ditambah.

2. Temu bual dijalankan oleh penulis di Yayasan Kepimpinan Perdana, Putrajaya.

3. Profesor Anthony Milner merupakan pakar sejarah Asia Tenggara. Temu bual dijalankan oleh penulis di Australian National University, Australia.

\section{Bibliografi}

Australia-Malaysia Institute. 2007. Celebrating 50 years of Australia-Malaysia. Canberra:

Department of Foreign Affairs and Trade Australia.

Australian. 1993. [Missing title], 24 November, 2. 1992. Mahathir says film widens rift, 17 March.

Australian Government, Department of Foreign Affairs and Trade. 2005. An AustraliaMalaysia free trade agreement: Australian scooping study. Canberra: Commonwealth of Australia.

2003. Malaysia country brief. Canberra: Australian Department of Foreign Affairs and Trade. Retrieved from https:/www.dfat.gov.au/geo/malaysia/Pages/ malaysia-country-brief (accessed 15 January 2019).

Baker, M. 1993. Keating's Malay jibe ends kow-towing. The Age, 24 November.

Barker, G. 1991. End Australia's wimpishness on regional issues. The Age, 15 March.

Barker, G., Daly, M. and Murdoch, L. 1993. Prime Minister shows defiance on Malaysia. The Age, 30 November. 
BBC News. 1998a. Malaysia complains about Australian leader's remarks, 23 September. Retrieved from http://news.bbc.co.uk/2/hi/asia-pacific/178609.stm (accessed 20 July 2019).

1998b. Australian PM raises Anwar case with Mahathir, 16 November. Retrieved from http://news.bbc.co.uk/2/hi/asia-pacific/215432.stm (accessed 18 June 2019).

Berita Harian. 2017. Sekurang-kurangnya perlu ada satu akaun unit Amanah, 4 September. Retrieved from https:/www.bharian.com.my/rencana/komentar/ 2017/09/321175/sekurang-kurangnya-perlu-ada-satu-akaun-unit-amanah (accessed 7 July 2019). 1993a. Australia tidak beradab: Mahathir, 24 November, 1.

1993b. Enggan menghadiri sidang APEC: Mahathir tidak kesal, 21 November, 1.

Bull, H. 1995. The anarchical society: A study of order in world politics (2nd Edition). London: MacMillan Press Ltd.

Burchill, S. 2005. The national interest in international relations theory. New York: Palgrave. https://doi.org/10.1057/9780230005778

Byrnes, M. 1994. Australia and the Asia games. Sydney: Allen \& Unwin.

Camilleri, R. 2001. Attitudes and perceptions in Australia-Malaysia relations: A contemporary profile. Selangor, Malaysia: Penerbit UKM.

Cochrane, P. 2001. Australians at war. Sydney: ABC Books.

Crouch, H. 1994. Malaysia. In The Asia-Australia survey, eds. R. Trood and D.J. McNamara, 195-206. Melbourne: MacMillan.

Dunne T. 2007. The English School. In International relations theories: Discipline and diversity, eds. T. Dunne, M. Kurki and S. Smith, 108-128. New York: Oxford University Press.

Fraser, M. 2001. An Australian critique. Australian Journal of International Affairs 55(2): 225-234. https://doi.org/10.1080/10357710120066911

Friedrichs, J. 2004. European approaches to the international relations theory: A house with many mansions. London: Routledge. https://doi.org/10.4324/9780203495551

Gunn, G.C. 2000. New world hegemony in the Malay world. New Jersey: The Red Sea Press.

Holsti, K.J. 2009. Theorizing the causes of order: Hedley Bull's "The Anarchical Society". In Theorizing international society: English School methods, ed. C. Navari, 125147. New York: Palgrave. https://doi.org/10.1057/9780230234475_7

Hugo, G. 2011. Malaysian migration to Australia. Malaysian Journal of Economic Studies 48(2): 147-174.

Johnson, C. 1993. History restarted: Japanese-American relations at the end of the century. In Pacific economic relations in the 1990s: Cooperation or conflict, eds. R. Higgott, R. Leaver and J. Ravenhill, 35-61. New York: Lynne Rienner Publishers.

Kelly P. 2010. The march of patriots: The struggle for Modern Australia. Victoria, Australia: Melbourne University Press. 
Knight, A. 2000. Fact or faction? The collision of journalism values in Asia. In Foreign devils and other journalists, eds. D. Kingsbury, E. Loo and P. Payne, 1-16. Victoria, Australia: Monash Asia Institute.

MacIntyre, A.J. 1993. Indonesia, Thailand and the Northeast Asian connection. In Pacific economic relations in the 1990s: Cooperation or conflict, eds. R. Higgot, R. Leaver and J. Ravenhill, 250-270. New York: Lynne Rienner Publishers.

Mahathir Mohamad. 2000. The Malaysian currency crisis: How and why it happened. Selangor, Malaysia: Pelanduk Publications. 1999. A new deal for Asia. Selangor, Malaysia: Pelanduk Publications.

Maniam, H.S. 1986. Kuala Lumpur executes two for drug convictions. AP News, 7 July. Retrieved from https://apnews.com/30cb86915d3e97c5f7e75d2d6fdd8c4a (accessed 28 June 2020).

Marshallsay, Z., ed. 1996. Australia-Malaysia relations: New roads ahead; Proceedings of the conference organised by the Centre of Malaysian Studies, 20 April 1995. Clayton: Monash Asia Institute.

Mauzy, D. 1999. Redefining a nation: Australia's efforts to gain acceptance for its policy of constructive engagement with Asia. The Round Table 88(350): 333-346. https://doi.org/10.1080/003585399108199

Mohamed Ariff. 2007. Economic openness, volatility and resilience: Malaysian perspectives. Kuala Lumpur: Malaysian Institute of Economic Research.

Mustafa K. Anuar. 2000. Malaysia: Country report. In Media and democracy in Asia, AMIC compilation. Singapore: Asian Media Information.

New Straits Times. 2003. Strong rhetoric will not affect KL-Canberra ties, 27 October. 1993a. Disgusted with the uncouth remarks of Australian PM, 2 December, 13. 1993b. Keating's insensitivity to blame, 5 December. 1993c. Straight talking versus offensive outburst, 8 December, 13. 1991. [Missing title], 21 June.

Paul, E. 1998. Australia in Southeast Asia: Regionalisation and democracy. Copenhagen: NIAS.

Schofield, A. 2000. Contemporary Malaysian national culture and foreign relations with Australia. In Foreign devils and other journalists, eds. D. Kingsbury, E. Loo dan P. Payne, 229-243. Melbourne: Monash Asia Institute.

Searle, P. 1996. Recalcitrant or realpolitik? The politics of culture in Australia's relations with Malaysia. In Pathways to Asia: The politics of engagement, ed. R. Robison, 56-84. Sydney: Allen \& Unwin.

Shamsul Amri Baharuddin. 1992. Malaysia in 2020, one state many nations? Selangor, Malaysia: UKM Press.

Skehan, C. 1998. Fall of Mahathir's golden boy. The Age, 4 September.

Snyder, C. 2015. Australia-Malaysia security cooperation as a pivotal component for more stable bilateral relations. Asian Politics and Policy 7(3): 379-393. https://doi.org/10.1111/aspp.12197

Thayer, C.A. 1992. Australia and South East Asia. In A changing world: New foreign policy dimensions, ed. F.A. Mediansky, 251-266. Sydney: Maxwell MacMillan Publishing Australia. 
The Age. 1998a. Mahathir faces mounting world criticisms, 26 September. 1998b. Mahathir steps up the attack on Anwar, 9 September. 1992a. Government dismissed a new film, 26 February. 1992b. Irresponsible and a big lie, 14 March. 1991a. Evans turns values into vices, 25 July. 1991b. Frank, open, productive, 22 July.

1990. Suspension of existing and future (non-essential) bilateral projects, 31 October. 1986a. Drug pair: Final plea is rejected, 7 July. 1986b. Malaysian MPs to send protest, 10 July.

The Australian Financial Review. 1998. Who's afraid of capitalism?, 7 September.

UNCOMTRADE. 2020. UN Comtrade database. Retrieved from https://comtrade.un.org/ (accessed on 10 January 2020).

Williams, B. 1992. Australia and Malaysia. Kuala Lumpur: Lai Publishing Pte. Ltd.

Wilson, P. 2013. Alternatives to realism: The English School of international relations. Retrieved from http://www.lse.ac.uk/internationalRelations/news/misc-news/ Wilson-ES-Bologna-.pdf (accessed 12 March 2019).

Wollcott, R. 2003. The hot seat. Sydney: Harper Collins Publishers.

WTO (World Trade Organization). 2001. United States: Import prohibition of certain shrimp and shrimp products. Dispute settlement DS58, 21 November. Retrieved from https://www.wto.org/English/tratop_e/dispu_e/cases_e/ds58_e.htm (accessed 14 September 2019).

Zainudin Maidin. 2008. Surat daripada Dr. Mahathir. Kuala Lumpur: Utusan Publications. 